\title{
European Significant Bank Stock Market Volatility: Is there a Bail-In Effect?
}

\author{
Paola Leone ${ }^{1}$, Pasqualina Porretta ${ }^{1} \&$ Luca Riccetti ${ }^{2}$ \\ ${ }^{1}$ Management Department, Sapienza University of Rome, Roma, Italy \\ ${ }^{2}$ Economics and Law Department, University of Macerata, Macerata, Italy \\ Correspondence: Luca Riccetti, Economics and Law Department, University of Macerata, via Crescimbeni 14, \\ 62100 Macerata, Italy. Tel: 39-0733-2583-276. E-mail: luca.riccetti@unimc.it
}

Received: January 31, 2019

Accepted: March 18, 2019

Online Published: April 18, 2019

doi:10.5539/ijbm.v14n5p32

URL: https://doi.org/10.5539/ijbm.v14n5p32

\begin{abstract}
In 2016 the "bail-in" tool, set by the European Bank Recovery and Resolution Directive (BRRD), started to enter into force: shareholders of European banks lose their money in the case of bank rescue. Before the "bail-in" mechanism was introduced, governments often performed bail-out of distressed banks. The larger risk born by shareholders can be observed in the growth of stock market volatility. We implement a panel data analysis on a sample of large European banks and find that in 2016 stock market volatility changes in a way that is theoretically consistent with the introduction of the "bail-in". Moreover, Italy shows an even higher volatility, probably due to retail investors owning bank shares, who could have understood the risk only after the burden sharing of four Italian banks in November 2015. These findings can be a warning about market efficiency, with implications for the systemic risk of a "bail-in" procedure.
\end{abstract}

Keywords: bail-in, bank resolution, stock market efficiency, stock market volatility

\section{Introduction}

In order to reduce costs for the tax payer related to bank bail-out, the European Parliament adopted (in spring 2014) a framework named Bank Recovery and Resolution Directive (BRRD)(Note 1) to give comprehensive and effective arrangements to the financial authorities to deal with failing banks. In particular the BRRD requires banks to prepare recovery plans to overcome financial distress, gives national resolution authorities the power to intervene before the situation of a bank deteriorates irreparably and, if a bank's situation becomes so distressed that its recovery within an appropriate time limit is no longer realistic, the BRRD grants national authorities the power to ensure an orderly resolution of failing banks with minimal costs for taxpayers.

The resolution framework in theory aims to avoid a significant adverse effect on the financial system and to maintain market discipline. The resolution plan has to be prepared in advance and depends on the characteristics of each bank. Various alternatives are provided by the BRRD: to sell only a part of the assets/business area; to create a bridge bank that allows to continue the most important functions (i.e. temporarily transfer good assets to a government-managed entity); to create a bad bank to separate good assets from bad ones (the impaired assets would be transferred to an asset management entity); to apply "bail-in" measures, i.e. convert debt to shares or write them down. Although the Directive entered into force on the first of January 2015; the bail-in procedures had to be applied from the first of January 2016. As is known, the hierarchy for the bail-in of creditors follows a creditor waterfall whereby the junior liabilities are bailed-in first, followed by the next (more senior) tranches upon depletion of each previous layer (see Table 1). In this manner, the costs of the bank resolution fall in theory not upon the taxpayers but, according to the established order, on bank shareholders and creditors. The bail-in tool has the ability to recapitalize a bank internalizing the costs of the crisis by involving the loss of certain classes of creditors through the obligatory conversion of debt instruments, their value reduction or their cancellation. However, the Resolution Authorities have to make sure that creditors do not have losses greater than the losses occurred if the bank had been submitted to ordinary insolvency proceedings ("No Creditor Worse Off Rule"). Where it is not possible to pursue the banking equilibrium conditions or to guarantee an adequate capitalization, a Resolution Fund intervention is expected up to a maximum of $5 \%$ of total liabilities, subordinated to the condition that at least $8 \%$ of total liabilities have already been subject to bail-in mechanisms. 
Therefore, the bail-in regulatory framework aims to recapitalize a bank in resolution or to provide capital for a bridge institution, in the case that liquidation of the bank is not possible due to negative externalities for the financial system. This does not exclude public support, but subordinates it to many constraints, which are supposed to incentivize market discipline, that is to incentivize creditors to bear the costs for monitoring the bank's risk (Avgouleas \& Goodhart, 2015). The ECB board (2015) argues that the bail-in, with its emphasis on early intervention, orderly resolution and going concern, is able to attenuate the "too big-to-fail" subsidy enjoyed by bigger banks by incentivizing their market discipline.

Despite the fact that the BRRD looks like a perfect regulatory framework design, some perplexity arises about the legal admissibility of its various aspects in different European regulatory and banking contexts. Moreover, a few months after the introduction of the BRRD, there was a substantial inequality effect following its application, also certified by the Financial Stability Review (2016). Since its introduction, the bail-in mechanism has generated direct effects (substantial "zeroing" of asset value of some savers) and indirect crises of confidence in the banking system. In this perspective, the first application of the BRRD framework seems to create negative externalities, generating systematic risk and amplifying idiosyncratic risk by reducing confidence in bank reliability. Nevertheless, it is important to underline that BRRD is a Resolution Regime but not an insolvency procedure; therefore, it needs additional detailed rules in order to operate in the context of the insolvency procedure framework of the different European countries. In this perspective, it can be considered a work in progress.

Table 1. Bail-in sequence in the case of resolution (BRRD scheme).

\begin{tabular}{ll}
\hline Order & Liabilities excluded \\
\hline 1- Common Equity Tier 1 & - Covered deposits \\
2- Additional Tier 1 & - Secured liabilities \\
3- Tier 2 & - Interbank operations with an original maturity shorter than seven days \\
4- Subordinated liabilities & - Liabilities arising from a fiduciary relationship with a customer \\
5- Other eligible instruments such as senior unsecured debt or & - Liabilities towards employees, tax and social security authorities and \\
deposits not covered by a deposit guarantee scheme & creditors who are critical for the daily functioning of the bank operations \\
\hline
\end{tabular}

Source: Author's elaboration on European Parliament (2014).

The highlighted problems can increase the stock market price volatility of European banks. Given that in 2016 the price volatility for these banks actually increased (see Figure 1 in Section 3.3), our paper tries to study the volatility of a sample of European banks in relation to their accounting values in order to understand if the peculiar behavior of banking sector volatility can be driven by a deterioration in health of the banking system or by other (or further) effects which could also be related to regulatory changes such as the introduction of bail-in. We focus on the year 2016 because it represents the moment of rupture and causes abnormal behavior of the stock market. Therefore, we build a panel data analysis to observe the determinants of stock market volatility in the period 2011-2016 and we perform our regression interacting the 2016 dummy with explanatory variables, in order to detect the presence of a change in the model in 2016, possibly due to the bail-in entry into force. Moreover, we introduce a dummy for the Italian banks in 2016, because in November 2015 four Italian banks underwent the burden sharing procedure, as an early application of the BRRD, with the writing off of stocks and subordinated debts. Indeed, a stylized fact is that the Italian banking sector shows an even higher volatility in 2016. The econometric analyses confirm a possible influence of the bail-in introduction on stock market volatility.

The analysis of stock market volatility and its determinants is very relevant because of real economic consequences of stock market volatility. There is a long line of research that shows how high volatility may lead to adverse outcomes or crises, via the so-called high volatility channel (Danielsson, Valenzuela, \& Zer, 2016). Moreover, a large number of studies underlines a strong theoretical connection between stock market volatility and economic growth; in particular many empirical studies (see, for instance, Schwert, 2011; Hafner \& Reznikova, 2012; Danielsson et al., 2016; FatihÖzte \& Ocal, 2017) show a positive relation between financial crises and stock market volatility and macroeconomic variables, identified in various papers with variables such as inflation, house market price index, GDP and so on (Note 2). Given that bank stock market volatility was one of the most visible indicators during the international financial crisis, within the post-crisis macro-prudential agenda, volatility is part of the macro-prudential toolkit of policymakers (Note 3). 
Therefore, the first aim of this paper is to study the determinants of stock market volatility of a sample of European banks under the hypothesis that bail-in applications can exacerbate idiosyncratic risk and create contagion/systemic risk (Note 4). To the best of our knowledge, our paper is the first attempt to perform a panel data analysis on the influence of bail-in introduction on the stock market of listed banks.

A related and relevant analysis performed in our paper is on the possible low level of stock market efficiency and the connected issue of retail investor protection. Indeed, the market should modify its stock evaluation since the BRRD approval in 2014. If there is a change in 2016, then we could probably reject the hypothesis of strong efficiency in stock markets. Moreover, Italy shows even higher volatility in 2016: this could be due to the strong presence of retail investors owning bank shares, who could have understood the risk related to the BRRD only after burden sharing of four Italian banks in November 2015. This finding can be a further warning about the level of market efficiency, with possible implications also for the systemic risk of a bail-in procedure. In Italy, the low efficiency level could be due, as already said, to the shareholder structure often characterized by the presence of small corporate and retail investors who are not informed and have low financial literacy and by a relatively lower presence of institutional investors. Indeed, as reported in European Banking Authority (EBA) and European Securities and Market Authority (ESMA) (2018) "retail investors of the euro area held EUR 262.4 billion or $12.7 \%$ of the EU bank debt securities issued to euro area investors", and Italy accounts for half of this amount (EUR 132.3 billion), followed by Germany (EUR 49.4 billion) and France (EUR 31.7 billion). In particular, "measured as a proportion of banks' total debt (36.9\%) and as a proportion of total banking sector assets (3.4\%), banks in Italy have the largest proportion of euro area retail holders" (EBA \& ESMA, 2018). Moreover, the EBA \& ESMA (2018) report states that "the analysis of some investors' complaints has shown that, in some cases, investors have been proactively approached by credit institutions and were wrongly given the impression that a recommended product was as safe as a deposit". Similar considerations about Italy are reported by Philippon \& Salord (2017): "Many investors may not have understood the risks they were taking and the misselling seems to have been on a large scale". This finding can be extended from subordinated debt instruments to stocks, supporting the idea that some Italian banks implement the unfair practice of selling their own stocks to their account holder (the so-called self-placement) without broadly warning about the actual risk. As highlighted by the EBA \& ESMA (2018) report, "bailing in retail holders may affect overall confidence in the financial markets (...), which could in turn possibly lead to bank runs" and the "fact that retail bondholders are also clients of the institution means that their bail-in would damage the customer base and reputation of the institution, which could in turn make it more challenging for resolution authorities to restore the franchise value and business viability of the institution after resolution". Therefore, these considerations "may raise significant consumer protection issues and affect the practical application of the resolution framework under the BRRD". Nevertheless, when the resolution authority prepares a resolution plan it must identify whether or not there are situations that present an impediment to the resolution. In this context, the presence of retail holders may play a role. For these reasons, given that "Misselling is clearly a critical issue in Italy" (Philippon \& Salord, 2017), this paper specifically focuses on the Italian banking sector.

The remainder of this paper is organized as follows. Section 2 contains a literature review. Section 3 describes the sample, the variables used, and the methodological framework. Section 4 describes the main findings of the research and Section 5 concludes with some reflections and policy implications of our findings, but also pointing out the limits of this research.

\section{Literature Review}

Our paper tries to analyze if there is an effect, probably related to the introduction of bail-in, in stock market reaction/volatility. In this perspective, it is related to the economic debate on the bail-in tool and, more in general, to the debate on banking regulatory framework.

\subsection{Theoretical Papers on Bail-in}

There seems to be a substantial convergence in the financial literature on the need of an integrated framework to improve banking system stability and resilience (Schoenmaker \& Gros, 2012; Huertas \& Nieto, 2012), but for many authors the BRRD framework could be improved. Many papers, in recent years, reflect on different aspects of the BRRD: public intervention, resolution plan, recovery plan and so on. However, one of the most controversial aspect is the bail-in tool. Chennells \& Wingfield (2015) provide an overview of bail-in, underlying that there is more than one way to carry out a bail-in. They explain some misconceptions related to bail-in and how bail-in can be used to stabilize the balance sheet of a failing firm until the firm can be restructured, and they describe some of the other elements that need to be in place, alongside the bail-in tool, in order to successfully resolve a large complex firm. 
Some papers analyze the bail-in tool theoretically. As already explained, the main goal of the introduction of bail-in is to reduce the use of taxpayers' money and limit excessive risk taking or, in other words, the moral hazard, resulting from widespread government support of the financial system. Indeed, in the first phase of international financial crises, governments were forced to inject capital into, or bail-out, some banks in order to prevent widespread disruption. Public interventions restored confidence and preserved financial stability, but with significant negative consequences in terms of sovereign fiscal positions. Instead, bail-in can allow the authorities to make sure that shareholders and creditors of a bank bear the costs of failure, without recourse to public funds, in respect of BRRD objectives. Regarding moral hazard, there is a simple conventional idea in the financial intermediation sector: government guarantees schemes or other types of public interventions induce financial institutions to take excessive risks. Allen, Carletti, Goldstein, and Leonello (2017) challenge this conventional idea by reviewing the role that these underlying assumptions play in the assessment of the desirability and effectiveness of government guarantees; they propose a new framework within which to consider them and conclude that new research is needed to evaluate the implications on banks and the financial system as a whole. Moreover, the literature on principal-agent problem (conflict of interest between the shareholders and the manager) underlines that moral hazard causes the manager (and not the shareholders) to select a high level of risk (see, for instance, Lai, Soumaré, \& Sun, 2012). Furthermore, Grosse (2017) reports that most of the large US banks that were bailed out during the financial crisis also forced out their chief executives and usually several other members of top management as a result. Therefore, even without the bail-in, Grosse states that the situation should not be overstated "since the large bank leaders know that that their own jobs depend on sound management".

Other theoretical papers, such as Diamond and Rajan (2011), Avgouleas and Goodhart (2015), and Persaud (2016), point out some further shortcomings of the bail-in procedure. Indeed, we can highlight many issues that the bail-in can raise. For instance, does it really help in solving the banking crisis? Can it trigger systemic risks? Regarding the former issue, an investor willing to invest funds in the recapitalization of the bank in crisis could be stopped by the bail-in prospect. Other market solutions, such as acquisition by another bank, can also be stopped: a potential buyer could wait to acquire the distressed bank after the bail-in procedure in order to reduce the acquiring costs. Indeed, the "No Creditor Worse Off Rule" aimed at protecting the creditors compares the losses for the creditors in the case of bail-in to the losses in the event of closure, and not to the losses in the case of alternative solutions, such as market rescue that becomes less attractive because of the bail-in mechanism. Moreover, in the case of the creation of a bridge institution, this could perform poorly because of the lack of trust after the loss of reputation, implying a withdrawal of capital and deposits that prevents a correct functioning of the bridge bank with consequent further losses. The cited lack of trust with possible consequent withdrawal of capital and deposits can involve many banks in the financial system, and this is part of the latter issue (the systemic risk).

Dewatripont (2014) discusses the pros and cons of bail-in, showing that financial instability can be more costly than bailouts. He suggests not to rule out prefunded bailouts as an alternative/complement to bail-in, especially when dealing with negative macroeconomic shocks.

Poyntner and Reininger (2018) focus on the implications of the bail-in regime change on consumer/investor protection, especially for socially more vulnerable households, and on the resulting risk for political acceptance and for the achievement of bail-in aims. Indeed, they observe the application in recent cases, focusing on the treatment of retail bond holders and exploring their distribution across income quantiles in the Euro area countries.

\subsection{Empirical Papers on Bail-in}

Besides theoretical papers, a growing literature strand tries to empirically analyze the effect of the bail-in procedures with different methodological approaches and in relation to different variables, in order to assess if some design enhancements are needed.

Conlon and Cotter (2014) examine this regulatory framework retrospectively in the context of failed European banks during the global financial crisis. In particular, they find that equity and subordinated bond holders would have been predominant losers from bail-in, while bail-in losses attributed to senior bond holders would have been limited, and no losses would have been imposed on depositors. They underline the presence of negative impacts on financial stability as a result of the losses of some asset categories subject to bail-in, with possible synchronous sales on the secondary market at the close of the bail-in procedure.

Hüser, Hałaj, Kok, Perales, \& Van der Kraaij (2018) construct a multi-layered network model (each layer represents the cross holding of securities of a specific seniority among the 26 largest euro area banking groups, 
using the European System of Central Bank proprietary data) to estimate: a) the direct contagion effect to creditors; b) the balance sheet effect, where they quantify up to which seniority layer banks require bail-in in order to fulfill prudential requirements; c) the effect of the bail-in on the network topology in each layer. They find respectively that: a) there is no direct contagion to creditor banks in the sense that no creditor bank defaults due to a bail-in at one of its counterparties; b) in the baseline scenario, shareholders and subordinated creditors are always affected by the bail-in, senior unsecured creditors in $75 \%$ of the cases; c) a bail-in significantly reshapes interbank linkages within specific seniority layers. The authors finally argue that the Recovery and Resolution framework will need to carefully consider the composition of banks' financial structure in order to set the level of capital requirements (in particular TLAC/MREL requirements) to avoid direct contagion and to avoid that creditors such as depositors are hit.

Pigrum, Reininger, and Stern (2016) provide an overview of the main arguments for and against the bail-in tool, and analyze the structure of the demand and supply side of bail-in-able bank debt securities in each Euro area country. Indeed, it is interesting to analyze who are the subjects that invest in bail-in-able debts issued by banks. They find that nearly $40 \%$ of all bail-in-able debt securities issued by Euro area banks are held outside the Euro area.

Giuliana (2017) analyzes the salient events regarding both the BRRD legislative process and the impositions of bail-in on specific distressed banks and tests if these indications of Authority commitments to bail-in were credible enough to drive a repricing of existing bonds. Therefore, he applies a difference-in-differences approach to yield spread between non-secured bonds and secured bonds.

Similarly to Giuliana (2017), Schäfer, Schnabel, \& Weder di Mauro (2016) investigate the market reactions of stock prices and credit default swap (CDS) spreads of European banks in order to gauge the extent to which it is expected that bail-in will become the new regime. They find evidence of increased CDS spreads and falling stock prices most notably after the bail-in in Cyprus. Moreover, they find that bail-in expectation depends on the sovereign fiscal strength, i.e. reactions are stronger for banks in countries with limited fiscal space for bailouts.

Boccuzzi and De Lisa (2017) examine what happened in Italy with the burden sharing of four small to medium-sized failing Italian banks in November 2015, analysing a unique proprietary database of the Italian Deposit Guarantee Scheme. The authors study the behaviour of bank debt holders in such stressful situations and find that the resolved banks incurred a significant loss of total funding since the start of their Special Administration procedure. When resolution is impending, creditors and depositors take flight dramatically; uninsured deposit run-off is stronger than the insured deposit one. They also underline that in the case of a solvent bank which sends public signals of weakness (capital shortfall), deposits seem to become «infected» and behave in a similar fashion. The results seem to confirm that market discipline and the resolution regime work best when the crisis is not systemic. In the presence of a systemic crisis the funding outflows can reasonably reach large proportions; they can have negative impacts on market confidence and affect other bank creditors with all the adverse knock-on effects on financial stability.

Even if some of the previously cited papers criticized some aspects of the bail-in tool, Covi \& Eydam (2018) show that the BRRD introduction is effective in reducing negative externalities on the risk-transfer between banks and sovereigns. Indeed, they study the two-way feedback process between European banks and sovereigns from 2012 to 2016, finding a pronounced feedback loop from 2012 to 2014, while in 2015-2016 the magnitude of the loop decreases and the spillovers become not statistically significant.

Crespi, Giacomini, and Mascia (2018) uses Italy as a laboratory for testing the effect of the bail-in rules on bank funding costs. They analyse the rate paid by 28 Italian banks on issued senior bonds comparing "bail-inable" to "nonbail-inable" bonds. The econometric analysis applies a dummy that equals one when a bond was issued after 1 January 2016, and zero otherwise. They find an increase of the spread at issuance in 2016 for "bail-inable" bonds. Moreover, the increase depends on bank characteristics: large institutions, banks with lower ratings, profitability, capitalization, and higher liquidity face a higher cost of issuing "bail-inable" bonds.

\subsection{Empirical Papers on Changes in Banking Regulation}

As Crespi et al. (2018), many papers exploit a regulatory change as a sort of "natural" experiment. We follow this literature strand, using the bail-in introduction. Our empirical paper studies the behavior of the stock market price of listed European banks potentially subjected to the rescue process required by the BRRD (for the sample, see subsection 3.2) with a panel data analysis. Indeed, the increased risk for large bank shareholders, compared to the previous period in which bail-out procedures were applied, could reduce the value and increase the price volatility of these stocks. The value reduction can be evaluated with the book to market ratio, as carried out by Jordan, Rice, Sanchez, \& Wort (2011) who study the effect of the 2008 Troubled Asset Relief Program (TARP) 
on the US banking system. We perform an analysis similar to that by Jordan et al. (2011), but we focus on the stock market volatility considering its strong relationship with the default probability. Vassalou \& Xing (2004) highlight the usefulness of stock price volatility to predict default probability, compared also to accounting values and bond quotations. Indeed, the stock market is forward looking compared to accounting values which are backward looking or compared to the official rating (given that a firm experiences a substantial change in its default risk prior to its rating change), and stock markets are often much more liquid than corporate bond markets. Moreover, Campbell \& Taksler (2003) find that firm volatility and credit ratings explain equally well the cross-sectional variation in corporate bond yields. Theoretically, firm stock price volatility is a key input for default probability calculation following the contingent claims methodology of Black \& Scholes (1973) and Merton (1974).

For these reasons, we analyze stock market volatility, differently from many papers in the literature that focus on subordinated bonds: see, for instance, Balasubramnian and Cyree (2011), Evanoff, Jagtiani, and Nakata (2011), Flannery and Sorescu (1996), Imai (2007), Krishnan, Ritchken, and Thomson (2005). However, an interesting extension of this work could be to repeat the current analysis on subordinate bond yields, because their risk profile is particularly influenced by the bail-in introduction (see the hierarchy for the bail-in reported in Table 1). Given that these instruments are quoted in much less liquid markets and it is more difficult to obtain a reliable and large dataset, we perform the analysis on stock price volatility even if, with efficient markets, among the instruments subject to the bail-in procedure, stocks should have modified their risk profile less with the introduction of bail-in given that they were already the instruments most at risk for absorbing the loss produced by all banking risks. However, the increased risk should influence in particular the stocks issued by more fragile banks and by banks owned by retail investors, for which the hypothesis of efficient markets is not reliable. Therefore, we expect to find a change in the determinants of stock price volatility especially for banks characterized by a fragile situation (undercapitalization, excess of non-performing loans, lack of liquidity...) and by a largely dispersed ownership.

Our paper contributes to the existing literature along a number of dimensions. First of all, to the best of our knowledge, this is the first attempt to perform a panel data analysis on the influence of the bail-in procedure on quoted instruments. Secondly, we analyze the market reaction of a regulatory change on stock volatility and not on bond yields, as the majority of these kinds of studies does (for instance, see the references reported above). We follow Jordan et al. (2011) in the analysis of the effect of a government intervention on stock market prices. However, compared to Jordan et al. (2011): (i) the analysis is, obviously, on bail-in and not on the TARP and consequently on EU banks and not on US banks (and in a different time span); (ii) the dependent variable is the stock price volatility and not the price to book value ratio. Thirdly, the analysis allows us to achieve important reflections on stock market efficiency and systemic risk.

\section{Methodology, Dataset and Variables}

\subsection{Recruitment}

We perform an econometric analysis (using Stata software) in order to study which bank characteristics have a greater influence on stock market volatility and if these characteristics change their influence on the dependent variable in 2016, when the bail-in procedure entered into force. In particular, we try to determine the stock market volatility using the following idiosyncratic explanatory variables (for details, see subsection 3.3): total assets, equity on total assets, ROA, net interest margin, gains on trading and derivatives activities, non-performing loans (NPLs) on total loans, reserves on NPLs, short-term funding on total assets, subordinated loans on total assets. Moreover, we add the year dummies in order to catch possible common time effects, especially due to the evolution of the sovereign debt crisis. Next, we interact the 2016 year dummy with the explanatory variables in order to observe the possible model change when the bail-in procedure entered into force. Moreover, observing a high price volatility for Italian banks in 2016, we add a further dummy to study if the bail-in introduction could have had a particular influence in this country, after the rescue in November 2015 of four small banks owned also by many small corporate and retail investors.

We start with a pooled ordinary least squares regression (POLS), and with static panel approaches, that is with random effects (RE) and with fixed effects (FE). After the estimates, we have to choose the favorite model among the pooled, random effects and fixed effects ones. Using Mundlak's approach (Mundlak, 1978), we find that the FE approach is preferable.

Moreover, given that the number of observations is limited compared to the number of explanatory variables, we use the $90 \%$ confidence interval in the analysis of our results and we perform the backward iteration process to the chosen model (the FE model), that is we delete the less significant variable until all variables have a p-value 
below $10 \%$. Reduced regression usually confirms the results of the full model and increases the statistical significance of some theoretically important variables.

We perform some robustness checks substituting some of the chosen variables with other proxies of the same bank features (see Table 3 in subsection 3.3).

Then, we check the presence of outliers and verify the robustness of the results to the removal of these "influential" observations. All these robustness checks confirm the baseline regression results.

\subsection{Dataset}

We analyze a balanced panel dataset of 33 listed European banks from 2011 to 2016, for an overall dataset of 198 observations. In particular, we compute the stock price volatility yearly on the daily closing price extracted from Datastream for the 2011-2016 period, and we regress this variable on accounting data regarding the previous fiscal year (that is the period 2010-2015). The source of the accounting data is Orbis Bank Focus (Bankscope). We consider the 2011-2016 period because these are the years in which the European Banking Authority (EBA) is created (2011) and the Single Rulebook and the Banking Union are developed. Substantially relevant are, in this context, the approval of the Capital Requirements Regulation (CRR, 2013), the Capital Requirements Directives (CRD IV, 2013) and the BRRD analyzed in this paper.

Some countries present more than one bank included in the sample, indeed there are 11 Italian, 6 Spanish, 3 German, 3 French, 2 Greek and 2 Portuguese banks. The list of banks is reported in Appendix A. We favour this sample with a larger component of Italian banks for two reasons: firstly, because of the peculiar features of the Italian banking sector, characterized by a large presence of retail investors and by the critical issue of "misselling", as explained in the Introduction. Secondly because, since the BRRD approval, Italy is one of the few countries that applied (in November 2015) a rescue process for four banks based on a large burden sharing procedure in line with the BRRD prescriptions. Indeed, up till 2014 the European banking crises were solved with public bail-out (the ECB estimates that banking rescues cost the European states 880 Euro billions) and, from BRRD approval to its entry into force on the first of January 2016, some other rescue procedures did not fully apply the BRRD provisions, but used different "intermediate" strategies following the burden sharing principle.

All analyzed banks are "significant" ones, therefore they are directly supervised by the European Central Bank. Indeed, they are mainly complex banking groups involving many financial institutions that diversify the activities carried out, following the "universal banking" business model with services to all market segments: retail, private, corporate and institutional. However, we can detect some differences: for instance, we can divide the business model of the central-northern Europe banks that adopt a fully diversified strategy (with commercial and investment banking activities, including asset management, private banking...), from the business model of the southern Europe banks that sometimes adopt a relatively "narrow" banking strategy (for instance focusing on the retail component or on a traditional commercial banking activity). Moreover, among banks established in different countries, we can observe different organizational structures and different governances, due to differences in historical evolutions and to slightly different legal frameworks (even if in the EU the legal framework is largely homogeneous). In particular, the shareholder structure is often characterized by a large fragmentation and by the presence of both domestic and international institutional investors, but it also presents peculiar aspects for different banks. Indeed, some banks have a very large component of retail investors (for instance, banks derived from privatization processes), some banks present large quotes held by institutional investors, private foundations and/or large industrial groups, and few banks present residuals of public property. Moreover, the need of new capital recently strengthened the presence of sovereign funds from emerging countries.

\subsection{Variables}

A large strand of literature tries to determine which variables can influence the stock prices or the book-to-market value or the bond yield of banks. Starting from some of the already cited papers (Balasubramnian \& Cyree, 2011, Evanoff et al., 2011, Jordan et al., 2011, Krishnan et al., 2005) and the references therein, we select some variables that are commonly associated with the riskiness of a bank. As explained by Flannery \& Sorescu (1996), the risk can be associated with some accounting measures such as "loan quality, leverage, interest rate risk exposure, and profitability".

Therefore, we estimate the following regression: 


$$
\begin{aligned}
& \mathrm{SV}_{\mathrm{t}+1}=\alpha+\beta_{1} \mathrm{TA}_{\mathrm{t}}+\beta_{2} \mathrm{CAP}_{\mathrm{t}}+\beta_{3} \mathrm{ROA}_{\mathrm{t}}+\beta_{4} \mathrm{NIM}_{\mathrm{t}}+\beta_{5} \mathrm{TD}_{\mathrm{t}}+\beta_{6} \mathrm{NPL}_{\mathrm{t}}+\beta_{7} \mathrm{RNPL}_{\mathrm{t}}+\beta_{8} \mathrm{ST}_{\mathrm{t}}+\beta_{9} \mathrm{SUB}_{\mathrm{t}}+\beta_{10} \mathrm{YEAR}_{\mathrm{t}+1}+ \\
& \beta_{11} \mathrm{ITA}_{2016}+\beta_{12} \mathrm{TA}_{\mathrm{t}}{ }^{*} \mathrm{D} 2016+\beta_{13} \mathrm{CAP}_{\mathrm{t}} * \mathrm{D} 2016+\beta_{14} \mathrm{ROA}_{\mathrm{t}}{ }^{* \mathrm{D} 2016}+\beta_{15} \mathrm{NIM}_{\mathrm{t}} * \mathrm{D} 2016+\beta_{16} \mathrm{TD}_{\mathrm{t}}{ }^{*} \mathrm{D} 2016+ \\
& \beta_{17} \mathrm{NPL}_{\mathrm{t}}^{*} \mathrm{D} 2016+\beta_{18} \mathrm{RNPL}_{\mathrm{t}}{ }^{* \mathrm{D}} 2016+\beta_{19} \mathrm{ST}_{\mathrm{t}} * \mathrm{D} 2016+\beta_{20} \mathrm{SUB}_{\mathrm{t}}^{*} \mathrm{D} 2016+\varepsilon_{\mathrm{t}+1}
\end{aligned}
$$

Where:

- $\quad \mathrm{SV}$ is the stock price volatility;

- $\quad$ TA are the total assets;

- $\quad$ CAP is the capitalization ratio computed as equity divided by total asset;

- $\quad$ ROA is the return on assets;

- $\quad$ NIM is the net interest margin;

- $\quad \mathrm{TD}$ is the ratio between net gain/losses on trading and derivatives and total assets;

- NPL is the ratio between non-performing loans (NPLs or impaired loans, generally defined as past due loans - unpaid past their due date) and gross loans;

- RNPL is the ratio between loan loss reserves and NPLs;

- $\quad$ ST is the short-term funding as the ratio between deposits, money market and others short term funding and total assets;

- $\quad$ SUB is the ratio between subordinated borrowing and total assets;

- $\quad$ YEAR is a set of time dummies one for each year excluding 2016 used as reference year.

The descriptive statistics and the correlation matrix among these variables are reported in the Appendix B.

Moreover, we add two further dummies:

- ITA2016: the dummy for the Italian banks in 2016 (equivalent to the product of the dummy for country Italy and the year dummy for 2016);

- D2016: the year 2016 dummy that is interacted with all the other variables in order to detect the possible presence of a structural change of the model in 2016 due to the introduction of bail-in.

The use of the dummy for Italy is due to the stylized fact that the Italian banking sector shows a very large volatility in 2016, as displayed in Figure 1 where we report the stock market volatility computed between January and November both in 2015 and in 2016 (we decided to avoid December because in 2016 the stock market volatility was artificially modified by the suspension of Monte dei Paschi di Siena from the market). Moreover, the gap between the volatility of the Italian banking system and the overall Euro Stoxx Banks index, that was present also in the previous years, grows considerably in 2016 (first and third column of Figure 1). The volatility growth of the Italian banking sector is not driven by a macroeconomic shock involving the volatility of the overall Italian stock market, indeed the FTSE MIB index shows a much less prominent volatility increase, and even this smaller volatility increase is due to the large weight of the banking sector on the whole index.

This country effect has two possible explanations: (i) health deterioration of the Italian banking system is more noticeable compared to the Eurozone banking sector; (ii) there is a further country specific effect which could be related to some peculiar features of the country and/or to the resolution of four banks at the end of November 2015 as an application of the BRRD, with the writing off of stocks and subordinated debt values. The latter explanation could be driven by the fact that the resolution of the four banks makes the investors really aware of the increased level of risk, especially in a country characterized by the presence of small corporate and retail investors who are uninformed and with low financial literacy, involving a poor level of efficiency of the stock market that was not able to absorb the implication of the BRRD approval in 2014.

Instead, the first explanation is related to the large consensus that the most relevant issue for the European banking sector now is the low profitability of many banks, especially in the south of Europe, and in particular in Italy. A banking system unable to generate profit will lose its solvency capacity. Moreover, Italy is characterized by a financial system based on a banking sector which, if hit by a crisis, can create relevant damage to the whole economy, increasing firm defaults that, by augmenting the NPLs for the banking system, can reinforce the bank crisis in a vicious circle. Indeed, the large stock of NPLs is one of the most relevant reasons of the current low profitability of Italian banks. Many Italian firms did not manage to survive the long economic crisis because they were characterized by a financial structure which was too leveraged (with debt towards the banking system), was too small and with a level of internationalization, R\&D investments and innovation which was too low. However, even if the large stock of NPLs is partially due to the effort of some banks to support the "real" economy (at least 
in the first part of the crisis; see Tutino, Colasimone, Brugnoni, \& Riccetti, 2017, for an analysis of the Italian banking system behavior between 2008 and 2012), this effort could be oversized not only by a wrong evaluation of the relevance of the crisis, but also because of the pressure made by stakeholders on banks requesting an effort beyond their "proper" role (stirring up many problems from the accounting of the firms to the accounting of the banks), resulting in some possible cases of illegal maladministration.

In order to distinguish between the two proposed views, we insert a dummy for the specific effect of Italy in 2016, that we call ITA_2016.

The year dummy 2016 concerns the bail-in procedure for large systemic banks that peremptorily enters into force in all Eurozone countries from the first of January 2016. Therefore, shareholders of the biggest banks of the Eurozone can really lose their money in the case of strong structural imbalance and solvency problems, before being rescued by the Single Resolution Fund and by the governments. This should imply a larger stock market volatility. Market data seems to support this idea, as shown in Figure 1: Euro Stoxx Banks index highlights a growth of the standard deviation from $1.7 \%$ in 2015 to $2.6 \%$ in 2016 (more than 50\% increase). Moreover, this growth is not driven by an aggregated shock that increases macroeconomic instability and, consequently, the overall stock market volatility. Indeed, in the same period, the standard deviation of the Euro Stoxx 50 index remains substantially unchanged or, rather, it decreases slightly from $1.5 \%$ in 2015 to $1.4 \%$ in 2016 . The peculiar behavior of the banking sector can be driven by an overall health deterioration of the banking system or by a structural change, probably due to the introduction of bail-in. In order to test this possibility, we perform our regression interacting the 2016 dummy with all the explanatory variables. If all coefficients, from $\beta_{12}$ to $\beta_{20}$, result jointly non-statistically significant then the stock market volatility growth is due to health deterioration of the banking system, otherwise there is a structural change that could be due to the introduction of bail-in.

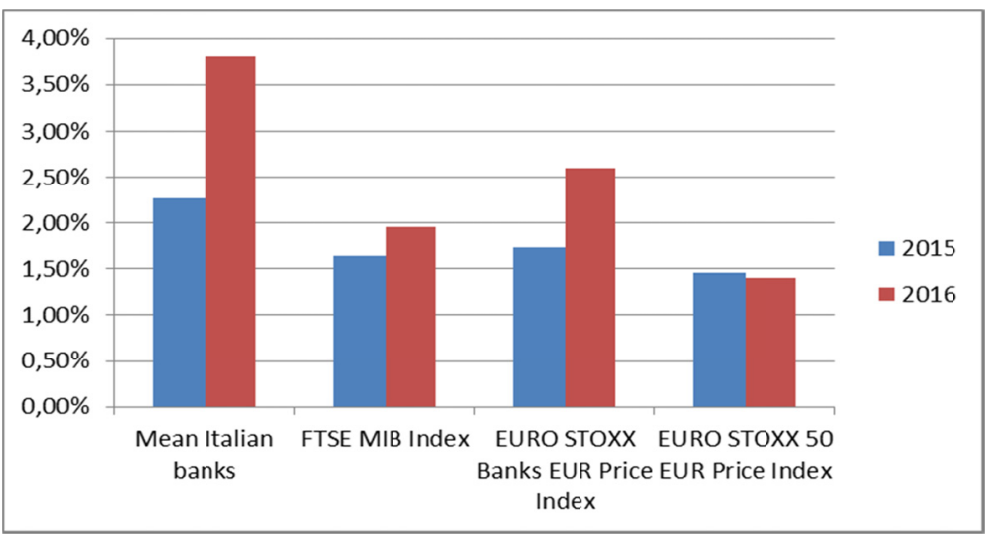

Figure 1. Stock market volatility (standard deviation) for Italian listed banks, the Italian stock market index (FTSE MIB), the EURO STOXX Banks index and the EURO STOXX 50 index. The standard deviation is computed between January and November 2015 and 2016.

Following the results usually found in the literature, we expect to observe some relationships between the chosen idiosyncratic independent variables and stock price volatility as proxy for bank riskiness. In particular, we expect to see an increase of stock price volatility when:

- the size, that is total assets or logarithm of total assets, decreases. Indeed, a larger bank could be more diversified and, overall, can receive stronger government help because it is too-big-to-fail. The latter feature should be true before the introduction of bail-in, therefore we expect that this feature has to disappear in the analysis on 2016. Consequently, we imagine a negative $\beta_{1}$ and a positive $\beta_{12}$ and the sum of the two should be not statistically significant;

- the capitalization (or the Tier 1 ratio) decreases, because a less capitalized bank has a larger leverage and is less resilient to losses. This effect could be magnified by the bail-in entry into force, even if it should be present in any case. Therefore, we expect a negative $\beta_{2}$ and a negative or not statistically significant $\beta_{13}$;

- the return on assets is reduced, because of worse profitability, for instance due to inefficient bank management, and increases the default risk. However, a higher ROA could also be associated to a riskier bank (because of the usual risk-return trade-off). The introduction of bail-in should not change the evaluation of the 
ROA. Thus, we expect a negative $\beta_{3}$, but we cannot exclude a positive sign, and a not statistically significant $\beta_{14}$; - the net interest margin diminishes, because of the worse profitability on the banking core business due, for instance, to lower interest spreads. However, a lower NIM could also be associated to less risky loans and to a reduced maturity transformation between assets and liabilities thus decreasing the default risk. The bail-in introduction should not change the evaluation of the NIM. Therefore, as for the ROA, we expect a negative $\beta_{4}$, but we cannot exclude a positive sign, and a not statistically significant $\beta_{15}$;

- the volume of trading and derivatives (gain/losses on trading and derivatives) increases, because these activities could be characterized by strong market risks and could bear high losses. However, these activities could also be associated to a lower default risk (in presence of well diversified and hedged trading portfolio), because they can present better liquidity compared to traditional loans, and can help the bank in its business diversification. The introduction of bail-in should not change the evaluation of this variable. Thus, we expect a positive $\beta_{5}$, but we cannot exclude a negative sign, and a not statistically significant $\beta_{16}$;

- the non-performing loans (NPLs) increase, because they represent a deterioration of the quality of loan assets, that implies higher losses (and consequently, higher impairment, loan loss reserves and capital requirements) due to the credit risk. The introduction of bail-in should not change the evaluation of this variable, even if this effect could be magnified by the bail-in entry into force. Therefore, we expect a positive $\beta_{6}$ and a not statistically significant (or positive) $\beta_{17}$;

- the reserves on NPLs decrease, because the bank is not adequately facing the credit risk due to NPLs. As for the NPLs, the introduction of bail-in should not change the evaluation of this variable, even if this effect could be magnified by the bail-in entry into force. Therefore, we expect a negative $\beta_{7}$ and a not statistically significant (or negative) $\beta_{18}$;

- the short-term funding increases, because it decreases the funding stability and increases the liquidity risk. The liquidity risk should be enlarged by the introduction of bail-in, because a reduced confidence in the financial system can increase the funding problem of banks. Therefore, we expect a positive sign for both $\beta_{8}$ and $\beta_{19}$;

- the presence of subordinated debt increases, because it could increase the cost of funding, especially after the introduction of bail-in. However, it could also reduce the default risk, improving the market discipline on the bank. Then, we expect a positive $\beta_{9}$, but we cannot exclude a negative sign, and a positive $\beta_{20}$.

Table 2 summarizes what we expect to find.

Table 2. Variables and expected sign of the coefficients

\begin{tabular}{|c|c|c|c|}
\hline Acronym & Variable & Proxy & Expected effect \\
\hline TA & Total assets & Size & $\beta_{1}-$ \\
\hline CAP & Equity on assets & Capitalization & $\boldsymbol{\beta}_{2}-$ \\
\hline ROA & Return on assets & Profitability & $\boldsymbol{\beta}_{3}-/+$ \\
\hline NIM & Net interest margin & Profitability on loans & $\boldsymbol{\beta}_{\mathbf{4}}-/+$ \\
\hline TD & Gain on trading and derivatives on assets & Volume of trading and derivatives & $\boldsymbol{\beta}_{5}+/-$ \\
\hline NPL & Non-performing loans on gross loans & Credit risk & $\boldsymbol{\beta}_{6}+$ \\
\hline RNPL & Loan loss reserves on NPLs & Credit risk & $\boldsymbol{\beta}_{7}-$ \\
\hline ST & Short term funding on assets & Liquidity risk & $\boldsymbol{\beta}_{\mathbf{8}}+$ \\
\hline SUB & Subordinated borrowing on assets & Cost of funding or market discipline & $\boldsymbol{\beta}_{9}+/-$ \\
\hline ITA2016 & Dummy country Italy in 2016 & Bail-in introduction in 2016 & $\boldsymbol{\beta}_{11}+$ \\
\hline TA*D2016 & Total assets & Bail-in introduction in 2016 & $\boldsymbol{\beta}_{12}+$ \\
\hline $\mathrm{CAP} * \mathrm{D} 2016$ & Equity on assets & Bail-in introduction in 2016 & $\mathbf{B}_{13}=/-$ \\
\hline NPL*D2016 & Non-performing loans on gross loans & Bail-in introduction in 2016 & $\mathbf{B}_{17}=/+$ \\
\hline RNPL*D2016 & Loan loss reserves on NPLs & Bail-in introduction in 2016 & $\mathbf{B}_{18}=/-$ \\
\hline $\mathrm{ST}^{*} \mathrm{D} 2016$ & Short term funding on assets & Bail-in introduction in 2016 & $\mathbf{B}_{19}+$ \\
\hline SUB*D2016 & Subordinated borrowing on assets & Bail-in introduction in 2016 & $\mathbf{B}_{\mathbf{2 0}}+$ \\
\hline
\end{tabular}

The results of the estimate of Equation 1 are reported in Table 4 and 5 in Section 4.1. However, we perform some robustness checks substituting some of the selected variables with other proxies of the same analyzed bank characteristics, as reported in Table 3. The results are reported in Table 6 in Section 4.2.1. 
Table 3. Variable used for the robustness checks.

\begin{tabular}{lll}
\hline Bank feature & Baseline regression variable & Alternative variable \\
\hline Size & Total Assets & Logarithm of total assets \\
Capitalization & Equity on total assets & Tier 1 ratio \\
Profitability & ROA & Operating profit on average total assets \\
\hline
\end{tabular}

\section{Results}

\subsection{Baseline Regression}

As already explained in the Methodology section, we analyze the dataset with a pooled ordinary least squares regression (POLS), and with the static panel approach, that is with random effects (RE) and with fixed effects (FE).

First, we add the year dummies in order to catch possible common time effects, especially due to the evolution of the sovereign debt crisis. We find these dummies statistically very significant and the regressions present a very good fit of the data (for instance the R2 of the POLS regression is 70.3\%). Despite the presence of year dummies, our residuals present heteroscedasticity problems pointed out by all heteroscedasticity tests (Breusch-Pagan, White, Modified Wald test for groupwise heteroscedasticity), even if the Wooldridge test for autocorrelation does not highlight the presence of autocorrelation. Given the presence of heteroscedasticity, we choose to use cluster-robust standard errors.

We also check for multicollinearity problems. All the continuous variables present a variance inflation factor (VIF) below 3 (see the last column of Table B1 in Appendix B), therefore there aren't any multicollinearity problems (obviously the multicollinearity increases including the variables interacted with the 2016 year dummy).

After the estimates, we have to choose the favorite model among the pooled, the random effects and the fixed effects ones. In order to choose between POLS and RE, we use the Breusch and Pagan Lagrangian Multiplier test for random effects and, in every case, the test rejects the null hypothesis (with a p-value below $1 \%$ ), therefore the RE model has to be preferred. To select the best model between the POLS and FE ones, we perform the F-test on all the dummies for the subject-specific effects (the fixed effects). We always reject (with a p-value well below 1\%) the null hypothesis that all dummies are jointly non-significant, therefore the FE model has to be used. In order to choose between the RE and FE regressions, we employ Mundlak's approach (Mundlak, 1978), that is a Hausman test using a procedure based on auxiliary regressions in order to overcome the heteroscedasticity problem. We find that the FE approach has to be preferred. Table 4 reports the results of the FE regression.

Moreover, we perform the backward iteration process. Reduced regression is reported in Table 5. It confirms the results of the full model and increases the statistical significance of some theoretically important variables.

Empirical evidence shows that stock market volatility of the large listed banks included in our sample:

- decreases (as expected) when capitalization (equity on total assets ratio) increases, because the market knows that the more capitalized financial intermediaries are more resilient;

- decreases (as expected) when the ROA increases, because of raising operational efficiency and a better profitability;

- increases when the net interest margin increases, probably because it could represent a bank strategy with a worse portfolio diversification, more exposed on traditional lending in a period of economic crisis and/or associated to riskier loans (higher credit risk and/or larger maturity transformation between assets and liabilities) with the consequent possible growth of NPLs. Moreover, this finding could be reinforced by the strong concern of the European Central Bank (for instance with the 2014 "Comprehensive Assessment") about the credit assets of the banks, compared to a relatively reduced focus on trading books and derivatives. Indeed, the problems related to a high level of NPLs (in conjunction with a low capitalization), together with a low interest rate environment and IT progresses, apply pressure on the traditional banking business model. As highlighted by Bonaccorsi di Patti, Felici, and Signoretti (2016), a diversified business model can stabilize bank performance in the business cycle. However, a change in the business model is neither simple nor achievable in a short time span, also requiring innovations and a change in the strategic vision of the top management, with a conciliation between short term commercial targets and long-term strategic targets which is not simple;

- increases (as expected) when the NPLs grow because the market perceives the larger credit risk (perhaps 
due to some critical issues in the credit risk process). However, this effect is reduced when reserves on NPLs grow, increasing the bank's financial solvency;

- $\quad$ is higher in 2011-2012 (especially in 2011) and then the constant coefficient stabilizes. The higher risk perceived in 2011 can be clearly related to the sovereign debt crisis, mitigating in 2012 and solved in 2013 after the ECB intervention;

- $\quad$ is not influenced by total assets value, gains/losses on trading and derivatives, and subordinated funding.

The result on trading and derivatives and on subordinated funding are consistent with the uncertain alternative explanation reported in Section 3.3. Instead, the result on total assets is unexpected. A possible explanation is that all banks are quite large, which prevents them from going bankrupt without government intervention.

Table 4. Estimates of the FE model with all variables interacted with the 2016 dummy (variables named with suffix "16")

\begin{tabular}{|c|c|c|c|c|c|c|}
\hline \multicolumn{4}{|c|}{$\begin{array}{l}\text { Fixed-effects (within) red } \\
\text { Group variable: Bank }\end{array}$} & \multicolumn{2}{|c|}{$\begin{array}{l}\text { Number of obs }= \\
\text { Number of groups }-\end{array}$} & $\begin{array}{r}198 \\
33\end{array}$ \\
\hline \multicolumn{4}{|l|}{ R-sq: } & \multicolumn{3}{|l|}{ obs $p$} \\
\hline within & 0.5329 & & & & $\min$ & \\
\hline between & 0.7023 & & & & avg $=$ & 6.0 \\
\hline$x=(\mathrm{u} i \mathrm{i}, \mathrm{xb})$ & $=0.0650$ & & & $\begin{array}{l}\text { F }(24,1 \\
\text { Prob }>\end{array}$ & $=$ & \\
\hline sv & Coef. & Std. Err. & $t$ & $P>|t|$ & 1958 Conf & Intervall \\
\hline TA & $1.74 e-11$ & $9.90 e-10$ & 0.02 & 0.986 & $-1.94 e-09$ & $1.97 e-09$ \\
\hline $\begin{array}{l}\text { TAP } \\
\text { CAP }\end{array}$ & $\begin{array}{r}1.148-11 \\
-.1108822\end{array}$ & .0653941 & $\begin{array}{l}-.02 \\
-1.70\end{array}$ & $\begin{array}{l}0.980 \\
0.092\end{array}$ & -.2401619 & $\begin{array}{r}.0183975 \\
.018397\end{array}$ \\
\hline $\mathrm{ROA}$ & -.2557124 & .0817604 & -3.13 & 0.002 & -.4173472 & -.0940777 \\
\hline NIM & .5062489 & .3558723 & 1.42 & 0.157 & -.1972864 & 1.209784 \\
\hline TD & .1864996 & .4246006 & 0.44 & 0.661 & -.6529067 & 1.025906 \\
\hline RNPL & -.0144901 & D112391 & -1 & 99 & -.036709 & .0077287 \\
\hline NPI & .0682557 & .0172364 & 3.96 & 0.000 & .0341805 & .1023309 \\
\hline ST & .0100767 & .0173515 & 0.58 & 0.562 & -.0242261 & .0443795 \\
\hline SUB & .0527825 & .1514058 & 0.35 & 0.728 & -.2465363 & .3521014 \\
\hline YEAR2011 & 1.555642 & 1.207891 & 1.29 & 0.200 & -.8322763 & 3.943559 \\
\hline 2 & 1.012981 & 1.2 & 0.84 & 0.401 & -1.36666 & 3.392622 \\
\hline & .2866557 & & 0.24 & 0.812 & -2.093604 & 2.666916 \\
\hline YEAR2014 & -.0313901 & 1.209635 & -0.03 & 0.979 & -2.422756 & 2.359976 \\
\hline YEAR2015 & .1154584 & 1.2150 & & 24 & -2.286566 & 2.517483 \\
\hline ITA2016 & .9215143 & .4461468 & & 1 & .0395126 & 1.803516 \\
\hline & $4.21 e-10$ & 3.5 & 1.19 & & -2 & $1.12 e-09$ \\
\hline & -.0733393 & .120503 & -0.61 & 0.544 & -.31 & .1648869 \\
\hline ROA16 & .3654776 & .5208694 & 0.70 & 0.484 & -.664 & 1.395201 \\
\hline NIM1 6 & .0215553 & .4260 & 0.05 & 0.960 & -.8206384 & .8637491 \\
\hline TD16 & .636361 & 1.315 & & 0.629 & -1.96444 & 3.237162 \\
\hline RNPL16 & .0026363 & $.01 \mathrm{C}$ & & & -.0189663 & .0242389 \\
\hline NPL1 6 & .0012917 & & & & -.0 & .0601583 \\
\hline ST16 & .0087151 & .014 & 0.62 & 38 & 2031 & .0366334 \\
\hline SUB16 & .1467 & & & & & .5263618 \\
\hline _cons & 1.466108 & 1.927083 & 0.76 & 0.448 & -2.343603 & 5.275819 \\
\hline & & & & & & \\
\hline & & & & & & \\
\hline & & Fo 5 & & & & \\
\hline
\end{tabular}

Table 5. Estimates of the reduced form with backward iteration of the FE model with all variables interacted with the 2016 dummy (variables named with suffix "16")

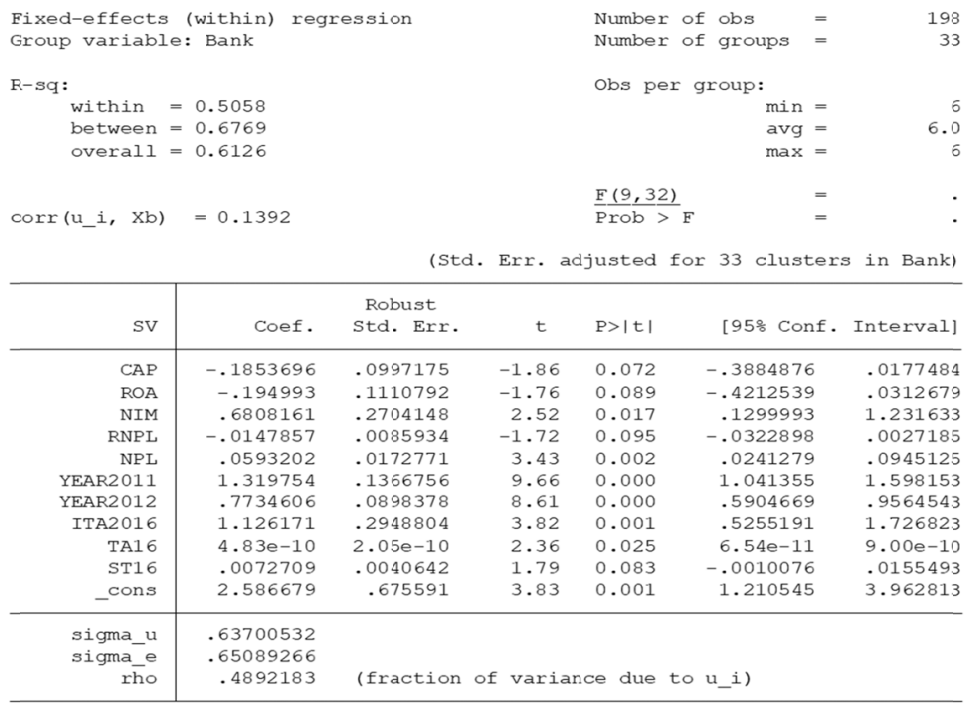


We find that 2016 presents a different behavior of some explanatory variables, therefore the bail-in can really imply some changes in the stock market evaluation of large banks. In particular:

- when the total assets increase, stock market volatility increases and it could be coherent with the loss of the too-big-to-fail perception for the bigger banks. However, the positive coefficient cannot be easily explained: as already said, we expected to find a significant negative coefficient before the bail-in and a non-statistically significant coefficient after the introduction of bail-in, instead we find a not statistically significant coefficient before the bail-in that becomes positive after bail-in introduction;

- when the short-term funding increases, stock market volatility increases because of the growing liquidity risk and the consequent possible presence of a monetary imbalance. This effect is present in 2016 and not in the previous period. Growing attention on the short-term funding issue in 2016 can be related to the introduction of bail-in and its systemic consequences on investors' confidence in the financial system. Indeed, the Italian experience shows that, after burden sharing in November 2015, the collection of deposits decline for the Italian banking system, because of the already mentioned reduced confidence in the financial system;

- the dummy ITA2016 is statistically significant and positive. Therefore, the Italian banking sector stock market volatility is relatively higher and it goes beyond the deterioration in health of the banking sector (emerging from a higher level of NPLs for the Italian banks or a lower level of capitalization) and beyond the overall change in the volatility of the whole sample in 2016. It indicates a further country specific effect, which could be related to some peculiar features of the country (for instance the macroeconomic situation) and/or due to an effect related to the introduction of bail-in after the resolutions made in November 2015. Obviously, we cannot discard the hypothesis that our model presents omitted relevant variables and the dummy ITA2016 catches the presence of omitted characteristics which are particular for Italy in 2016, or other features that could have a distinctive influence on Italy in 2016. However, this result is a strong clue that the reason could be related to the particular effect of bail-in introduction in Italy, especially after the resolution of four banks at the end of November 2015. Moreover, even a possible misspecification due to an omitted variable could be related to a structural change in model parameters in 2016 due to the introduction of bail-in itself.

All these findings can be signs of the effect of the bail-in.

A related and relevant consideration is on the possible low level of market efficiency. Indeed, the market should have modified its stock evaluation since the BRRD approval in 2014. If there is a change in 2016 and it is stronger in Italy after the November 2015 burden sharing (as an early application of the BRRD) with the resolution of four banks that makes the investors really aware of the increased risk level, then we could probably reject the hypothesis of strong efficiency in stock markets. However, as already explained, the efficiency level could be lower in Italy because the shareholder structure is often characterized by the presence of small corporate and retail investors, who are not informed and have low financial literacy, and by a relatively lower presence of institutional investors. This consideration can also support the idea that some Italian banks implement the unfair practice of selling their own stocks to their account holder without broadly warning about the actual risk.

\subsection{Robustness Checks}

We perform some robustness checks that largely confirm the reported results.

\subsubsection{Alternative Variables}

Firstly, we substitute some of the previously listed variables with the alternative variables reported in the last column of Table 3. The methodology is always a panel analysis with fixed effects. We perform this analysis both on the estimate implemented with all the variables and on the estimate implemented with the variables reported in Table 5 that contains the reduced form after the backward iteration. Both robustness checks confirm the main results obtained. Table 6 reports the results obtained with the reduced form. 
Table 6. Estimates of the robustness checks on the reduced form presented in Table 5 and reported here in the first column (baseline)

\begin{tabular}{|c|c|c|c|c|c|}
\hline Variable & Baseline & $\operatorname{lnTA16}$ & Tier1 & OP & Outliers \\
\hline CAP & $\begin{array}{l}-.185 \\
(0.0723)\end{array}$ & $\begin{array}{l}-.181 \\
(0.0795)\end{array}$ & & $\begin{array}{l}-.244 \\
(0.0037)\end{array}$ & $\begin{array}{l}-.185 \\
(0.0749)\end{array}$ \\
\hline ROA & $\begin{array}{l}-.195 \\
(0.0888)\end{array}$ & $\begin{array}{l}-.200 \\
(0.0829)\end{array}$ & $\begin{array}{l}-.315 \\
(0.0000)\end{array}$ & & $\begin{array}{l}-.189 \\
(0.1022)\end{array}$ \\
\hline NIM & $\begin{array}{l}.681 \\
(0.0170)\end{array}$ & $\begin{array}{l}.614 \\
(0.0284)\end{array}$ & $\begin{array}{l}.378 \\
(0.0782)\end{array}$ & $\begin{array}{l}.664 \\
(0.0365)\end{array}$ & $\begin{array}{l}.710 \\
(0.0155)\end{array}$ \\
\hline NPL & $\begin{array}{l}.059 \\
(0.0017)\end{array}$ & $\begin{array}{l}.059 \\
(0.0016)\end{array}$ & $\begin{array}{l}.039 \\
(0.0000)\end{array}$ & $\begin{array}{l}.059 \\
(0.0052)\end{array}$ & $\begin{array}{l}.059 \\
(0.0021)\end{array}$ \\
\hline RNPL & $\begin{array}{l}-.015 \\
(0.0950)\end{array}$ & $\begin{array}{l}-.014 \\
(0.1383)\end{array}$ & $\begin{array}{l}-.014 \\
(0.1251)\end{array}$ & $\begin{array}{l}-.010 \\
(0.3273)\end{array}$ & $\begin{array}{l}-.015 \\
(0.1024)\end{array}$ \\
\hline YEAR2011 & $\begin{array}{l}1.320 \\
(0.0000)\end{array}$ & $\begin{array}{l}1.330 \\
(0.0000)\end{array}$ & $\begin{array}{l}1.258 \\
(0.0000)\end{array}$ & $\begin{array}{l}1.255 \\
(0.0000)\end{array}$ & $\begin{array}{l}1.279 \\
(0.0000)\end{array}$ \\
\hline YEAR2012 & $\begin{array}{l}.773 \\
(0.0000)\end{array}$ & $\begin{array}{l}.784 \\
(0.0000)\end{array}$ & $\begin{array}{l}.784 \\
(0.0000)\end{array}$ & $\begin{array}{l}.812 \\
(0.0000)\end{array}$ & $\begin{array}{l}.776 \\
(0.0000)\end{array}$ \\
\hline ITA2016 & $\begin{array}{l}1.126 \\
(0.0006)\end{array}$ & $\begin{array}{l}.941 \\
(0.0011)\end{array}$ & $\begin{array}{l}1.252 \\
(0.0004)\end{array}$ & $\begin{array}{l}1.041 \\
(0.0004)\end{array}$ & $\begin{array}{l}1.123 \\
(0.0007)\end{array}$ \\
\hline TA16 & $\begin{array}{l}4.83 \mathrm{E}-10 \\
(0.0248)\end{array}$ & & $\begin{array}{l}4.94 \mathrm{E}-10 \\
(0.0261)\end{array}$ & $\begin{array}{l}4.64 \mathrm{E}-10 \\
(0.0300)\end{array}$ & $\begin{array}{l}4.75 \mathrm{E}-10 \\
(0.0264)\end{array}$ \\
\hline ST16 & $\begin{array}{l}.007 \\
(0.0831)\end{array}$ & $\begin{array}{l}-.006 \\
(0.6060)\end{array}$ & $\begin{array}{l}.005 \\
(0.3217)\end{array}$ & $\begin{array}{l}.008 \\
(0.0282)\end{array}$ & $\begin{array}{l}.007 \\
(0.0838)\end{array}$ \\
\hline $\operatorname{lnTA} 16$ & & $\begin{array}{l}.058 \\
(0.0731)\end{array}$ & & & \\
\hline Tier1 & & & $\begin{array}{l}.002 \\
(0.9157)\end{array}$ & & \\
\hline OP & & & & $\begin{array}{l}-.029 \\
(0.7163)\end{array}$ & \\
\hline CONST & $\begin{array}{l}2.586 \\
(0.0006)\end{array}$ & $\begin{array}{l}2.602 \\
(0.0006)\end{array}$ & $\begin{array}{l}2.105 \\
(0.0019)\end{array}$ & $\begin{array}{l}2.718 \\
(0.0012)\end{array}$ & $\begin{array}{l}2.550 \\
(0.0009)\end{array}$ \\
\hline
\end{tabular}

We can highlight some differences compared to the baseline model: first, the variable RNPL (loan loss reserves on NPLs), that is marginally significant at $10 \% \mathrm{p}$-value in the baseline regression, is not statistically significant in other specifications. Second, the variable ST16 (short term funding after bail-in introduction) is statistically significant only in two of the four robustness checks. Third, the regression with Tier 1 ratio instead of the equity on total asset ratio shows a not statistically significant Tier 1 ratio; the same applies to the operating profits used instead of ROA. However, when including Tier 1 or operating profits as explanatory variables, the other coefficients of the regressions do not present significant changes. Indeed, all regressions substantially confirm the findings showed in Table 5: capitalization ratio and ROA are inversely related with volatility, NPLs are directly related, reserves on NPLs are inversely related (even if they are statistically significant at $10 \%$ only in 1 out of 4 regressions), volatility is higher in 2011-2012 and in Italy in 2016. Moreover, total assets, confirmed by the logarithm of total asset, present a change in 2016 coherent with the loss of the too-big-to-fail perception due to the bail-in introduction. In some cases, such as for the variable NPL, the value of the coefficient is even the same in almost all regressions. Overall, there are no statistically significant coefficients that change their sign.

\subsubsection{Outliers}

Even if the fixed effects model can already partially address the issue of outliers, to further check the robustness of our results, we analyze the presence of outliers. Therefore, we perform an analysis of leverage, Cook's distance and DFBetas. We find that four banks (two Greek and two Italian ones) could be considered as outliers: Alpha, Carige, Eurobank Ergasias and Monte dei Paschi di Siena. We repeat the estimates after deleting these four banks and results are reported in the last column of Table 6 . Results are very robust: the significant variables do not change their signs and coefficients are almost unaffected. We only signal two very minor changes: ROA and RNPL modify their p-value from slightly below $10 \%$ to slightly above $10 \%$.

They are all fixed effects models. The last column ("Outliers") contains the estimate without four banks 
evaluated as outliers. LnTA is the logarithm of total assets, Tier1 is the Tier 1 ratio, OP is the operating profit on average total assets. We report the coefficient estimate and, below (in brackets), the respective p-value.

\section{Conclusions}

In many countries, the default of a bank is usually managed differently from the default of a firm working in another industrial sector. Indeed, before the bankruptcy administration, there is a management administration phase in order to reduce the negative effects on the financial and economic systems. Moreover, the rescue of a bank often implies the rescue of the investments of shareholders and creditors of the bank, producing a widespread feeling that the financial instruments issued by banks are almost risk free. These bail-outs often involve large costs for the public budget. In order to reduce the costs for the tax payer and to break the vicious circle between banking crises and sovereign debt crises, the European Union approved the BRRD that contains a new framework for the banking crisis management, including the so-called "bail-in".

Furthermore, the BRRD aims at improving the market discipline and at reducing the moral hazard risk of banks that appear too-big-to-fail.

However, the BRRD has raised a lot of criticisms and many Governments use complex law dispensations in order to avoid the bail-in procedure (see, for instance, the case of Banca Monte dei Paschi di Siena in Italy or, before the BRRD entrance into force, the case of Hsh Nordbank in Germany when the European Commission allowed public help without the burden sharing application). In other cases, after the bail-in application, Governments have to refund the households that lose their money invested in subordinated bonds in order to reduce the growing reputational risk (for instance, the case of Andelskassen in Denmark). Indeed, the loss of confidence in the banking system can cause serious damage to the whole financial and economic system (systemic risk). For instance, a panic selling of banking instruments in the markets can create financial instability, or low confidence in the financial system can reduce the collection of deposits (and make it more expensive) thus reducing the credit supply.

A stylized fact that can be easily related to the introduction of bail-in, is the very large volatility of the stock market prices of Italian banks in 2016, after the fact that in November 2015 four Italian banks underwent the burden sharing procedure, as an early application of the BRRD, with the writing off of stocks and subordinated debts sold also to small corporate and retail investors, the creation of four bridge banks and of a bad bank. The presence of local retail investors and of banking foundations owning deposits, bonds and shares are quite a particular Italian characteristic that, on one hand, gives "patient" funds to the banks but, on the other hand, can create a widespread "panic crisis" with consequent large fluctuations of stock market returns involving the whole banking system because retail investors are not sufficiently informed to discriminate financially sound banks from banks in distress. Moreover, this panic should be more focused on subordinated bondholders given the radical change in their risk after the introduction of the bail-in. Nothing changes at a theoretical level for shares and hybrid instruments intended to become capital if the equity is not sufficient to absorb the losses. However, as already explained, in the past the bail-out procedure also saved shareholders and holders of hybrid instruments by using external funds (usually public ones). A stock market turmoil is a symptom of this belief about the almost risk-free nature of bank shares; furthermore, the fact that in Italy it happens after the burden sharing of four banks means that many investors were unaware of the risk and of the legislation change due to the BRRD.

In this paper we use an econometric analysis in order to assess if the above considerations are supported by empirical evidence. Hence, we analyze if there is a change in stock market volatility in 2016 and if Italy presents an even stronger and particular effect due to the burden sharing of November 2015 and the distinctive shareholder structure of Italian banks. We find that in 2016 the model for stock market volatility changes and the changes can be theoretically consistent with the introduction of bail-in. Moreover, Italy shows even greater volatility. Therefore, we can affirm that:

- before bail-in introduction the investors feel that the shares of banks are not very risky, otherwise the bail-in should have had a limited impact on the expectations of shareholders (and hence on the equity prices), since equity investment should always have been considered a risky investment whose value is canceled in case of default;

- the stock market efficiency is low given that the BRRD should have been effective since its approval in 2014. Moreover, the higher volatility level in Italy, where there is a strong presence of retail investors owning bank shares who could have understood the contents of the BRRD only after the burden sharing of November 2015 , reinforces the above consideration.

As already said, we cannot discard the hypothesis that our model presents omitted relevant variables able to 
explain the different behavior of the model in 2016. However, this result is a strong clue that the introduction of bail-in could have implied higher stock market volatility not driven by an overall health deterioration of the banking system, detectable from the accounting data used as independent variables in our models (for instance, the capitalization or the percentage of NPLs).

Moreover, the present analysis should be extended to subordinated and senior debts. Indeed, the bail-in procedure implies that a bank is rescued with the conversion of subordinated and senior bonds, each according to its seniority. Therefore, it may be interesting in the future to conduct a similar research, specifically based on these instruments.

Regarding our interpretation on market efficiency, we cannot affirm with certainty that the markets present low efficiency and presence of irrational investors, because we can alternatively assume that investors hypothesize flexible behavior of the European Commission in BRRD application. However, even though we cannot say if the bail-in procedure applied to a large bank can trigger a systemic crisis, the above findings can be a warning signal not to overstate market efficiency and the rationality of investors.

These findings support the need to check the BRRD, as already planned in meetings of the European financial ministers, in order to correct some aspects of the regulation. However, the way to improve the BRRD is still under debate. For instance, regarding consumer protection issues, in order to solve the problems connected to "misselling" to retail investors, Philippon and Auser (2017) on the one hand, propose a revision of the CRD IV and MiFID (Markets in Financial Instruments Directive), including "a rule that retail investors cannot be sold directly to retail investors. They can, of course, choose to be exposed to such debt, but only via diversified mutual funds". On the other hand, EBA and ESMA (2018) propose that "an exemption based on Article 44(3) of the BRRD or Article 27(5) of the SRMR can be applied to the retail instruments". In practice, the former proposal asks for a tighter and more defined regulation to avoid uncertainty and discretionary decisions, while the latter asks for a more flexible regulation to avoid contagion and "a disproportionate destruction in value".

The World Bank finds that in all the recent banking crises there is no pre-existing resolution plan, nor a pre-defined loss absorbency capacity composed of bonds issued to be converted in case of default. However, these two conditions are determinant for a successful application of the bail-in procedure. Indeed, the bail-in tool has been applied since January 2016 while the loss-absorbing capacity in the Banking Union is being implemented in 2019 (with the MREL/TLAC requirements). Therefore, there is a gap between the capacity of the financial regulator to bail-in the liabilities of financial institutions and the existing "bail-inable" liabilities on banks' balance sheets. Consequently, such a radical regulation change should have been introduced in a longer time span with a slow phase-in, in order to avoid financial turmoil and the consequent attempt of governments to circumvent the bail-in procedure, weakening the credibility of the whole BRRD.

\section{Acknowledgments}

The authors thank the participants of the 8th International Conference, "Financial Engineering and Banking Society" (FEBS), Università of Roma Tre, Roma, June 4-6 2018, and the 5th "Financial Intermediation Network of European Studies" (Finest) Conference, Università LUM Jean Monnet, Trani, September 27-28 2017.

\section{References}

Aggarwal, R., Incan, C., \& Leal, R. (1999). Volatility in Emerging Stock Markets. Journal of Financial and Quantitative Analysis, 34(1), 33-55. https://doi.org/10.2307/2676245

Allen, F., Carletti, E., Goldstein, I., \& Leonello, A. (2017). Moral hazard and Government Guarantees in the Banking Industry. European Central Bank. https://doi.org/10.1093/jfr/fju003

Avgouleas, E., \& Goodhart, C. (2015). Critical Reflections on Bank Bail-ins. Journal of Financial Regulation, 1, 3-29. https://doi.org/10.1093/jfr/fju009

Balasubramnian, B., \& Cyree, K. B. (2011). Market discipline of banks: Why are yield spreads on bank-issued subordinated notes and debentures not sensitive to bank risks? Journal of Banking \& Finance, 35, 21-35, https://doi.org/10.1016/j.jbankfin.2010.07.015

Bessler, K. N. (2015). Time-varying systematic and idiosyncratic risk exposures of US bank holding companies. Journal of International Financial Markets. https://doi.org/10.1016/j.intfin.2014.11.009

Black, F., \& Scholes, M. (1973). The pricing of options and corporate liabilities. Journal of Political Economy, 81(3), 637-654, https://doi.org/10.1086/260062

Boccuzzi, G., \& De Lisa, R., (2017). Does Bail-in Definitely Rule out Bailout? Journal of Financial Management, Markets and Institutions, 5(1), 93-110. https://doi.org/10.12831/87061 
Bonaccorsi di Patti, E., Felici, R., \& Signoretti, F. M. (2016). Euro area significant banks: main differences and recent performance. Bank of Italy occasional paper n. 306.

Brunnermeier, M. K., \& Sannikov, Y. (2014). A Macroeconomic Model with a Financial Sector. American Economic Review, 104(2), 379-421. http://dx.doi.org/10.1257/aer.104.2.379

Campbell, J. Y., \& Taksler, G. B. (2003). Equity volatility and bond yields. The Journal of Finance, 58, 2321-2350. https://doi.org/10.1046/j.1540-6261.2003.00607.x

Chennells, L., Wingfield, V. (2015). Bank failure and bail-in: an introduction. Bank of England Quarterly Bulletin, $3,228-241$.

Conlon, T., \& Cotter, J. (2014). Anatomy of bail-in. Journal of Financial Stability, 15, $257-263$. https://doi.org/10.1016/j.jfs.2014.04.001

Covi, G., \& Eydam, U. (2018). End of the sovereign-bank doom loop in the European Union? The Bank Recovery and Resolution Directive. https://doi.org/10.1007/s00191-018-0576-2

Crespi, F., Giacomini, E., \& Mascia, D. V. (2018). Bail-in rules and the pricing of Italian bank bonds. https://doi.org/10.1111/eufm.12206

Danielsson, J., Valenzuela, M., \& Zer, I. (2016). Learning from History: Volatility and Financial Crises. Finance and Economics Discussion Series Divisions of Research \& Statistics and Monetary Affairs Federal Reserve Board. Washington. D.C..

Dewatripont, M. (2014). European banking: bailout. bail-in and state aid control. International Journal of Industrial Organization, 34, 37-43. https://doi.org/10.1016/j.ijindorg.2014.03.003

Diamond, D. W., \& Rajan, R. G. (2011). Fear of Fire Sales. Illiquidity Seeking. and Credit Freezes. The Quarterly Journal of Economics, 126(2), 557-591. https://doi.org/10.1093/qje/qjr012

European Banking Authority and European Securities and Market Authority. (2018). Statement of the EBA and ESMA on the treatment of retail holdings of debt financial instruments subject to the Bank Recovery and Resolution Directive. EBA/Op/2018/03.

European Central Bank. (2015). Opinion of the European central Bank of 2 September 2015 on bank resolution (CON/2015/31). Retrieved from https://www.ecb.europa.eu/ecb/legal/pdf/en_con_2015_31_f_sign.pdf

European Parliament. (2014). Directive 2014/59/eu of the european parliament and of the council of 15 May 2014.

Evanoff, D. D., Jagtiani, J. A., \& Nakata, T. (2011). Enhancing market discipline in banking: The role of subordinated debt in financial regulatory reform. Journal of Economics and Business, 63, 1-22. https://doi.org/10.1016/j.jeconbus.2010.07.001

Financial Stability Review. (2016). May. Special features. Retrieved from https://www.ecb.europa.eu/pub/fsr/shared/pdf/sfbfinancialstabilityreview201605.en.pdf?ba65e03fbfd38b61 $314915 \mathrm{e} 65 \mathrm{a} 9133 \mathrm{ce}$

Flannery, M. J., \& Sorescu, S. M. (1996). Evidence of Bank Market Discipline in Subordinated Debenture Yields: 1983-1991. The Journal of Finance, 51(4), 1347-1377. https://doi.org/10.2307/2329397

Giuliana, R. (2017). Bail-in's Effects on Banks' Bond Yields and Market Discipline. A Natural Experiment. Retrieved from https://ssrn.com/abstract=2935259

Grosse, R. (2017). The Global Financial Crisis-Market Misconduct and Regulation from a Behavioral View. Research in International Business and Finance, 41, 387-398. https://doi.org/10.1016/j.ribaf.2017.04.056

Hafner, C. M., \& Reznikova, O. (2012). On the estimation of dynamic conditional correlation models. Computational Statistics and Data Analysis, 56(11), 3533-3545. https://doi.org/10.1016/j.csda.2010.09.022

Huertas, T. F., \& Nieto, M. J. (2012). Banking union and bank resolution: how should the two meet? Retrieved from http:/www.voxeu.org/article/banking-union-and-bank-resolution-how-should-two-meet

Hüser, A. C., Hałaj, G., Kok, C., Perales, C., \& Van der Kraaij, A. (2018). The systemic implications of bail-in: a multi-layered network approach. Journal of Financial Stability, 38, 81-97. https://doi.org/10.1016/j.jfs.2017.12.001

Imai, M. (2007). The emergence of market monitoring in Japanese banks: Evidence from the subordinated debt market. Journal of Banking \& Finance, 31, 1441-1460. https://doi.org/10.1016/j.jbankfin.2006.07.007 
Jordan, D. J., Rice, D., Sanchez, J., \& Wort, D. H. (2011). Explaining bank market-to-book ratios: Evidence from 2006 to 2009. Journal of Banking \& Finance, 35, 2047-2055. https://doi.org/10.1016/j.jbankfin.2011.01.017

Krishnan, C. N. V., Ritchken, P. H., \& Thomson, J. B. (2005). Monitoring and Controlling Bank Risk: Does Risky Debt Help? The Journal of Finance, 60(1), 343-378. https://doi.org/10.1111/j.1540-6261.2005.00732.x

Lai, V. S., Soumaré, I., \& Sun, Y. (2012). Financial guarantors' executive compensation. charter value and risk-taking. Research in International Business and Finance, 26(3), 387-397. https://doi.org/10.1016/j.ribaf.2012.03.002

Fatih Öztek, M., \& Öcal, N. (2017). Financial crises and the nature of correlation between commodity and stock markets. International Review of Economics \& Finance, 48, 56-68. https://doi.org/10.1016/j.iref.2016.11.008

Merton, R. C. (1974). On the pricing of corporate debt: The risk structure of interest rates. The Journal of Finance, 29, 449-470. https://doi.org/10.2307/2978814

Minton, B. A., Stulz, R. M., Taboada, A. G. (2017). Are larger banks valued more highly? Fisher College of Business Working Paper 2017-03-008. https://doi.org/10.2139/ssrn.2921286

Mundlak, Y. (1978). On the Pooling of Time Series and Cross Section Data. Econometrica, 46(1), 69-85. https://doi.org/10.2307/1913646

Persaud, A. D. (2016). A ticking time bomb: TLAC and other attempts to privatise bank bail-outs. Butterworths Journal of International Banking and Financial Law, 160-163.

Philippon, T., \& Salord, A. (2017). Bail-ins and Bank Resolution in Europe: A Progress Report. Geneva Reports on the World Economy Special Report 4.

Poyntner, P., \& Reininger T. (2018). Bail-in and Legacy Assets: Harmonized rules for targeted partial compensation to strengthen the bail-in regime. Oesterreichische Nationalbank. working paper n.224.

Pigrum, C., Reininger, T., \& Stern, C. (2016). Bail-in: who invests in noncovered debt securities issued by euro area banks? Financial Stability Report 32. December.

Schäfer, A., Schnabel, I., \& Weder, B. (2016). Bail-in expectations for European banks: Actions speak louder than words. CEPR Discussion Paper N. DP11061.

Schoenmaker, D., \& Gros, A. (2012). An European Deposits Insurance and Resolution Fund - An update. CEPS Policy Brief N. 283.

Schwert, W. G. (2011). Stock Volatility during the Recent Financial Crisis. European Financial Management, 17, 789-805. https://doi.org/10.1111/j.1468-036X.2011.00620.x

Todea, A., \& Petrescu, D. (2012). Sudden changes in volatility - the case of the five Financial Investment Companies in Romania. Procedia Economics and Finance, 3, 40-48. https://doi.org/10.1016/S2212-5671(12)00118-9.

Tutino, F., Colasimone, C., Brugnoni, G. C., \& Riccetti, L. (2017). The determinants of lending to customers: evidence from Italy between 2008 and 2012. In M. H. Bilgin, H. Danis, \& E. Demir. U. Can (Eds.), Empirical Studies on Economics of Innovation. Public Economics and Management (pp. 57-102).

Vassalou, M., \& Xing, Y. (2004). Default Risk in Equity Returns. The Journal of Finance, 59(2), 831-868. https://doi.org/10.1111/j.1540-6261.2004.00650.x

\section{Notes}

Note 1. European Parliament (2014), DIRECTIVE 2014/59/EU OF THE EUROPEAN PARLIAMENT AND OF THE COUNCIL of 15 May 2014

Note 2. Obviously, financial literature find that the opposite causal relation is also at work: global and regional macroeconomic events are the most important shocks affecting volatility, creating the breakpoints in the volatility time series (see, for instance, Aggarwal, Incan, \& Leal, 1999, or Todea \& Petrescu, 2012).

Note 3. Policymakers are also trying to use volatility as an early warning signal of future financial and economic instability. However, financial literature find contrasting evidences. Indeed, many papers show that also very low volatility is a significant predictor of banking crises. Indeed, low volatility is followed by credit growth, indicating that investors are more likely to assume high risk in periods of low volatility, consistently with the 
Minsky instability hypothesis, thus increasing the likelihood of a crisis. Brunnermeier and Sannikov (2014) identify what they term the "volatility paradox" where low risk can paradoxically increase the probability of a systemic event.

Note 4. Bessler, Kurmann, \& Nohl (2015) contribute to understand the structure and time-variation of systematic and idiosyncratic risks for banks. They study US bank holding companies for the 1986-2012 period by decomposing total risk into systematic market-wide risk, systematic banking-industry risk, and idiosyncratic bank risk.

\section{Appendix A}

Banks in the sample, with the name of their home country and the value of their total asset at the end of 2015.

\begin{tabular}{lll}
\hline Name & Country & Total Assets - th EUR \\
\hline Aareal & GERMANY & 51.948 .000 \\
Alpha & GREECE & 69.296 .200 \\
Banca Carige & ITALY & 30.298 .900 \\
Banca Monte dei Paschi di Siena & ITALY & 169.012 .000 \\
Banca Popolare dell'Emilia Romagna & ITALY & 61.261 .200 \\
Banca Popolare di Milano & ITALY & 50.203 .300 \\
Banca Popolare di Sondrio & ITALY & 35.537 .600 \\
Banco Bilbao Vizcaya Argentaria & SPAIN & 750.078 .000 \\
Banco Comercial Português & PORTUGAL & 74.884 .900 \\
Banco de Sabadell & SPAIN & 208.627 .800 \\
Banco Popolare & ITALY & 120.509 .600 \\
Banco Popular Espanol & SPAIN & 158.649 .900 \\
Banco Santander & SPAIN & 1.340 .260 .000 \\
Bank of Ireland & IRELAND & 130.960 .000 \\
Bankinter & SPAIN & 58.659 .800 \\
Barclays & UK & 1.524 .497 .667 \\
BNP Paribas & FRANCE & 1.994 .193 .000 \\
Caixa Geral de Depositos & PORTUGAL & 100.901 .000 \\
Commerzbank & GERMANY & 532.641 .000 \\
Crédit Agricole & FRANCE & 1.529 .294 .000 \\
CREDEM & ITALY & 37.455 .300 \\
Deutsche & GERMANY & 1.629 .130 .000 \\
Erste & AUSTRIA & 199.743 .400 \\
Eurobank Ergasias & GREECE & 73.553 .000 \\
ING & NETHERLANDS & 841.769 .000 \\
Intesa Sanpaolo & ITALY & 676.496 .000 \\
KBC & BELGIUM & 252.356 .000 \\
Mediobanca & ITALY & 70.710 .600 \\
Nordea & FINLAND & 301.590 .000 \\
Société Générale & FRANCE & 1.334 .391 .000 \\
Swedbank & SWEDEN & 236.306 .131 \\
UniCredit & ITALY & 860.433 .400 \\
UBI & ITALY & 117.200 .800 \\
\hline
\end{tabular}




\section{Appendix B}

\section{Descriptive statistics}

Table B1. Descriptive statistics for the baseline model variables, including the Variance Inflation Factor (VIF) values of the independent variables

\begin{tabular}{llllll}
\hline Variable & Mean & Std. Dev. & Min & Max & VIF \\
\hline SV & 2.89 & 1.36 & 1.22 & 9.84 & \\
TA & $4,89 \mathrm{E}+08$ & $5.96 \mathrm{E}+08$ & $2.63 \mathrm{E}+07$ & $2.16 \mathrm{E}+09$ & 1.80 \\
CAP & 6.10 & 2.02 & -.968 & 13.07 & 2.56 \\
ROA & -.02 & 1.01 & -6.702 & 4.43 & 1.63 \\
NIM & 1.66 & .61 & .37 & 3.15 & 1.90 \\
TD & .08 & .16 & -.68 & .60 & 1.19 \\
NPL & 9.71 & 8.54 & .44 & 50.43 & 1.84 \\
RNPL & 54.18 & 16.21 & 28.81 & 117.1 & 1.14 \\
ST & 59.20 & 13.54 & 27.49 & 92.49 & 1.94 \\
SUB & 1.57 & .89 & .02 & 3.79 & 1.30 \\
\hline
\end{tabular}

Table B2. Correlation matrix among the baseline model variables

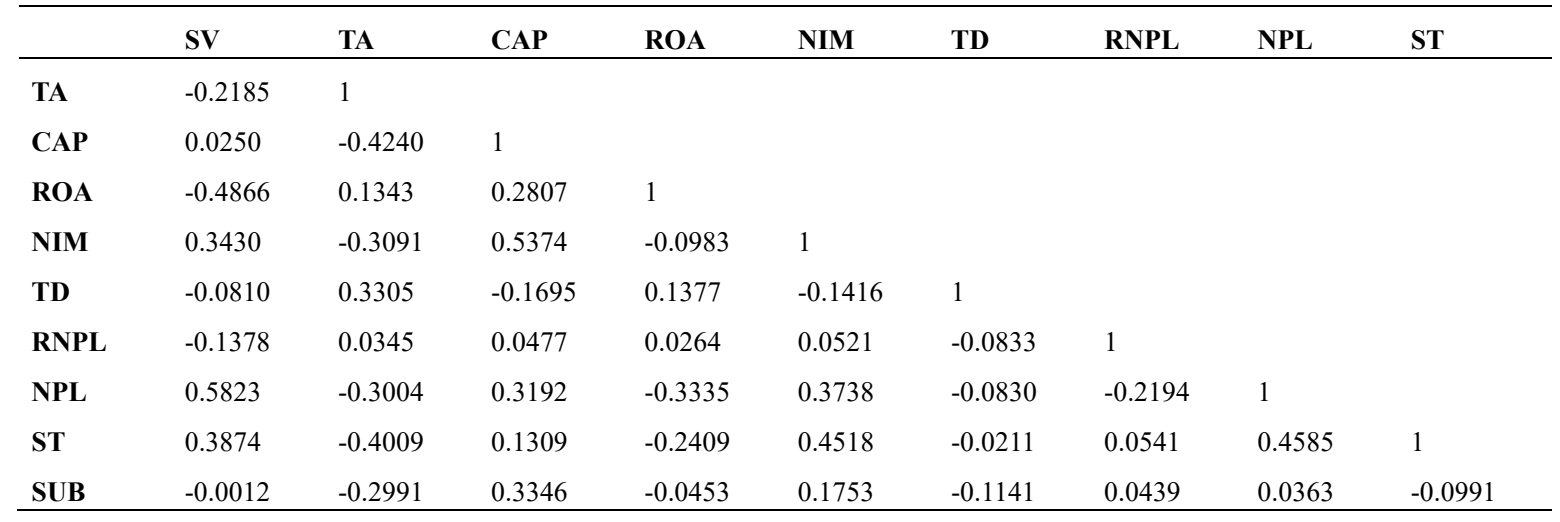

\section{Copyrights}

Copyright for this article is retained by the author(s), with first publication rights granted to the journal.

This is an open-access article distributed under the terms and conditions of the Creative Commons Attribution license (http://creativecommons.org/licenses/by/4.0/). 